\title{
日本応用動物昆虫学会誌
}

\section{第63巻 第1号}

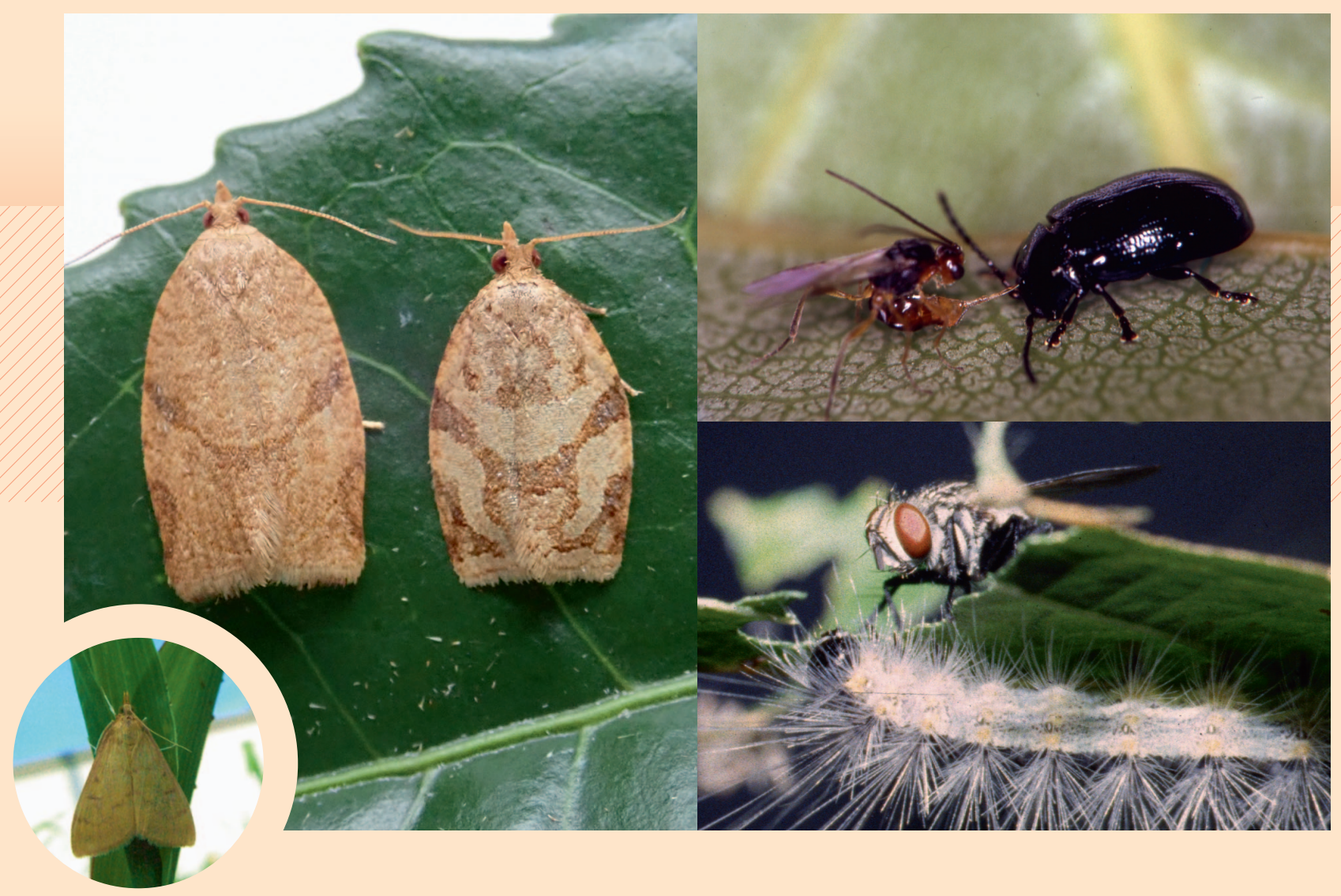

一般社団法人

日本応用動物昆虫学会

The Japanese Society of

Applied Entomology \& Zoology

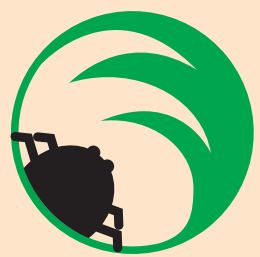

http://odokon.org/ 